Original Research

\title{
Distribution Characteristics and Assessment of Heavy Metals in the Surface Water of the Syr Darya River, Kazakhstan
}

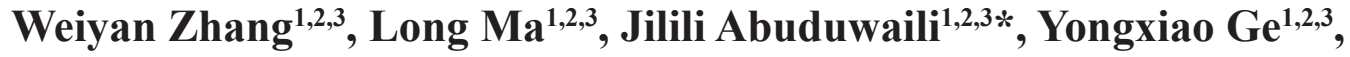 \\ Gulnura Issanova, ${ }^{2,4}$, Galymzhan Saparov ${ }^{2,5}$ \\ 'State Key Laboratory of Desert and Oasis Ecology, Xinjiang Institute of Ecology and Geography, \\ Chinese Academy of Sciences, Urumqi 830011, China \\ ${ }^{2}$ Research Center for Ecology and Environment of Central Asia, Xinjiang, Urumqi, China \\ ${ }^{3}$ University of Chinese Academy of Sciences, Beijing 100049, China \\ ${ }^{4}$ Faculty of Geography and Environmental Sciences, Al-Farabi Kazakh National University, \\ Ave. Al-Farabi, 75V, Almaty, 050040 Kazakhstan
}

${ }^{5}$ Uspanov Kazakh Research Institute of Soil Science and Agricultural Chemistry, Almaty, 050060 Kazakhstan

Received: 12 November 2018

Accepted: 12 February 2019

\begin{abstract}
The distribution characteristics and pollution assessment of aquatic environment and human health of eight heavy metals $(\mathrm{Zn}, \mathrm{Cu}, \mathrm{Pb}, \mathrm{Cd}, \mathrm{Ni}, \mathrm{Co}, \mathrm{Mn}$ and $\mathrm{Fe}$ )were measured in surface water of the Syr Darya River within Kazakhstan. The distribution characteristics results showed that the high content of $\mathrm{Zn}, \mathrm{Cu}$ and $\mathrm{Pb}$ samples concentrated in southern Kazakhstan, and another high content of $\mathrm{Cu}$ samples concentrated at the entrance to the Aral Sea, the high contents of $\mathrm{Fe}$ and $\mathrm{Cd}$ samples mainly concentrated in the downstream area of Kyzylorda, the high contents of Co and Ni samples distributed throughout the study area, and the high contents of Mn mainly concentrated upstream in the Kyzylora. A comparison with strict maximum permissible concentration standards for fisheries showed that the impact of current heavy-metal concentrations on fisheries is worrying. The heavy metal pollution index showed that the heavy metal pollution in the research area is high. The health risk assessment of heavy metals in the surface water indicated that $\mathrm{Cd}$ can cause a significant carcinogenic risk to human health and it should be a priority target of heavy-metal pollutant control in the region. The results have reference significance for regional water environment and repair of the Aral Sea.
\end{abstract}

Keywords: distribution characteristics, heavy metal assessment, surface water, Syr Darya River, Kazakhstan

*e-mail: jili1@ms.xjb.ac.cn 


\section{Introduction}

In the past few years, heavy metals in aquatic environments have drawn global attention due to their enrichment, environmental toxicity and persistence [1-4]. A large number of hazardous chemicals, especially heavy metals, have been released into rivers worldwide because of the rapid growth of the global population, the intensification of domestic activities and the expansion of industrial and agricultural production $[5,6]$. These developments will not only pollute the aquatic environment but also seriously threaten the survival of humans and other living things. Heavy metals are a major part of various serious components of pollution and have a much more harmful influence on the environment than radioactive and organic pollutants [7]. The sources of heavy metals mainly include geological erosion, weathering, and other natural sources; mining; metal processing; chemical production wastewater; the application of pesticides and fertilizers; household waste; and other artificial pollution sources. Heavy metals are easily enriched, difficult to degrade in the natural environment through microorganisms, etc., and ultimately enter the human body through the food chain, causing harm to the health of humans, aquatic organisms and their predators. Some adverse effects, such as cancer, deformities, liver and kidney dysfunction, and genotoxic carcinogenicity are due to heavy metal pollution [8-11].

The Syr Darya is the longest river in Central Asia and flows through Kyrgyzstan, Tajikistan, Uzbekistan and Kazakhstan, and finally into the Aral Sea; this river is the most important irrigation water resource in Central Asia, and at least half of the Central Asian population lives in this basin, it has great social, economic and ecological importance as it provides water for millions of people in the region, and habitat for a variety of aquatic animals [12]. The Syr Darya is a transboundary river in an arid area where various pollutants are distributed over the river. In addition, the awareness of aquatic environmental protection is weak, the national water management system is imperfect and water-management collaboration among neighboring countries is lacking, which make the overall water quality of the river poor - especially in terms of heavy metal pollution. The landscape, geography and biochemical characteristics, as well as the lithological mineral composition of the surrounding territory, contribute to the higher content of heavy metals in rivers in arid areas, while the arid climate conditions and alkaline soil properties make the mobility of elements such as mercury, zinc, cadmium, antimony, chromium and cobalt in the rivers of this arid region high [13, 14]. Part of Kazakhstan is the most ecologically and environmentally sensitive area in the whole basin; it is also the main life-supporting freshwater artery of southern Kazakhstan [15]. Anthropogenic activities such as mining and tailing accumulation, the ultimate disposal of treated and untreated waste effluents containing toxic metals as metal chelates from different industries, and contamination from intensive agricultural activities that use mineral fertilizers have become potential sources of heavy-metal contamination in the surface water of the Syr Darya River [15-17]. Therefore, it is especially important to understand the state of heavy metals in the aquatic environment of the study area.

Previous studies on heavy metal pollution in surface water in the study area have simply described the state of heavy metals in the region $[16,18,19]$, but there is no detailed evaluation of the possible harm to the environment and human body caused by current heavymetal concentrations. To better understand the potential hazards of heavy metals in surface waters in the study area, this study used an analysis of the mathematical statistics of heavy metals in water samples, the strictest maximum-permissible-concentration standards of the fishery industry and the heavy metal pollution indexto evaluate the influence of heavy metals on the aquatic environment, and the generally used United States Environmental Protection Agency (U.S. EPA)recommended human health risk assessment models to evaluate the degree of harm that heavy metals may pose to the environment and the human body.

\section{Experimental}

\section{Description of the Study Area}

The study area is located in the middle and lower reaches of the Syr Darya River in Kazakhstan. The part is $1400 \mathrm{~km}$ in length, and the drainage area is $21.84 \times 10^{4} \mathrm{~km}^{2}$. It flows through southern Kazakhstan and Kyzylorda and is the main freshwater resource of South Kazakhstan [18]. In the territory of Kazakhstan, the largest tributary is the Arys River, which flows down from the southwestern Kalaou Ridge; the river thereafter has no direct tributary flow into the Aral Sea and forms a large delta in the town of Kazaritsi. A total of $38.1 \%$ of the water in Kazakhstan is accounted for by the runoff of the Syr Darya River, which has an average annual flow of $179 \times 10^{8} \mathrm{~m}^{3}$, of which $137 \times 10^{8} \mathrm{~m}^{3}$ is derived from other countries. The volume consumed is $69 \times 10^{8} \mathrm{~m}^{3}$, and the available water resource volume is $110 \times 10^{8} \mathrm{~m}^{3}[20]$.

\section{Sample Collection and Preparation}

Forty-two surface water samples were collected from the Shardara reservoir to the north Aral Sea entrance in June 2017, the geographical location of the samples are shown in Fig. 1. The sampling points were located on bridges or other floating structures suitable for the collection of water samples. Approximately 500 $\mathrm{mL}$ of water was collected from each point and placed in a clean polyethylene container. After collection, the sample was filtered using a $0.45 \mu \mathrm{m}$ membrane and immediately acidified with $\mathrm{HNO}_{3}$ with a volume 


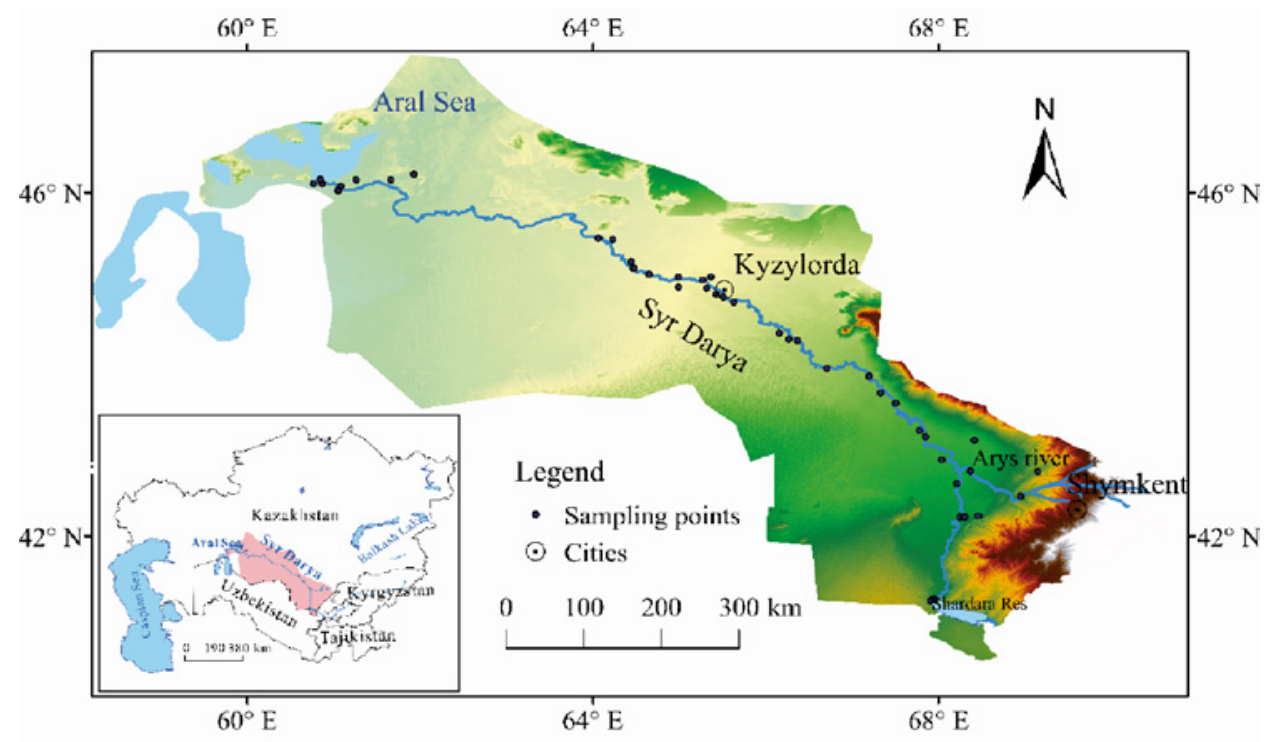

Fig. 1. Study area location and sampling point distribution.

ratio of $50 \%$ to a $\mathrm{pH}$ of approximately 2 to preserve heavy metals while avoiding precipitation. The basic physical and chemical properties of the water samples, including temperature, $\mathrm{pH}$, dissolved oxygen and electrical conductivity, were measured by a portable multi-parameter water quality analyzer (HQ40d, Hach Corporation, USA) at the same time. The probes were calibrated before the physical and chemical parameters of the water were measured. All the samples were stored in a $4^{\circ} \mathrm{C}$ refrigerator for analysis.

\section{Analytical Methods for Chemical Parameters}

Water samples were analyzed for heavy metals ( $\mathrm{Zn}, \mathrm{Cu}, \mathrm{Pb}, \mathrm{Cd}, \mathrm{Ni}, \mathrm{Co}, \mathrm{Mn}$, and $\mathrm{Fe}$ ) using a flame atomic absorption spectrometer (JENOPTIK Group, contrAA $\AA 300$ ) under standard operating conditions. Quality assurance and quality control were carried out with parallel experiments, blank tests and recovery tests. The recovery rates were between $90 \%$ and $110 \%$, and the relative deviations of parallel tests were within $10 \%$. All used acids and reagents were of analytical grade. All these analyses were performed at the Sino-Kazakh joint test center in Almaty, Kazakhstan.

\section{Heavy Metal Pollution Index}

The heavy metal pollution index (HPI) mainly indicates the influence of a single heavy metal on the comprehensive pollution of an aquatic environment and reflects the importance of individual characteristics relative to the whole environment. HPI is based on the weighted arithmetic-average method and is determined in two steps. First, weighting values are used to establish a rating scale for each selected parameter, and then the index of the pollution parameter is selected [21]. The scoring system comprises arbitrary values between 0 and 1 , whose choice depends on the importance of individual quality considerations, or HPI can be evaluated by comparing the values to the recommendations of the corresponding parameters [22, 23]. In calculating HPI, Prasad and Bose [24] believe that the unit weight (Wi) is inversely proportional to the recommended standard (Si) of the corresponding parameters.

The Kazakhstan drinking water standards for metals [25] were used for calculating $\mathrm{Wi}$, with the exception of $\mathrm{Pb}$ and $\mathrm{Co}$, for which no standard is provided. Instead, the standards for $\mathrm{Pb}$ and Co established by WHO [26] were used for the calculations. The standard values used for $\mathrm{Zn}, \mathrm{Cu}, \mathrm{Pb}, \mathrm{Cd}, \mathrm{Ni}, \mathrm{Co}, \mathrm{Mn}$ and Fe were 5.00, 1.00, $0.01,0.01,0.10,0.05,0.10$, and $0.30 \mathrm{mg} / \mathrm{L}$, respectively.

The formula of the HPI model [23] is given as follows.

$$
\mathrm{HPI}=\frac{\sum_{i=1}^{n} W_{i} Q_{i}}{\sum_{i=1}^{n} W_{i}}
$$

...where $\mathrm{W}_{\mathrm{i}}$ is the unit weight of the ith parameter and $\mathrm{n}$ is the number of parameters considered. $\mathrm{Q}_{\mathrm{i}}$ is the subindex of the ith parameter. The formula used to calculate $\mathrm{Q}_{\mathrm{i}}$ is given as follows:

$$
Q_{i}=\sum_{i=1}^{n} \frac{\left\{M_{i}(-) I_{i}\right\}}{\left(S_{i}-I_{i}\right)} \times 100
$$

...where $\mathrm{M}_{\mathrm{i}}$ is the monitored heavy metal content for the ith parameter, $I_{i}$ is the ideal value of the ith parameter and $S_{i}$ is the standard value of the ith parameter. The sign (-) indicates the numerical difference between the two values, ignoring the algebraic sign. The critical pollution index of the HPI value for drinking water as given by Prasad and Bose [24] is 100. However, a modified scale divided into three levels after Edet and Offiong [27] can also be used. The classes are divided into low, medium and high for HPI values as $<15,15-30$ and $>30$, respectively. 


\section{Human Health Risk Assessment}

Heavy metals enter the human body by a variety of routes, such as the food chain, skin contact and inhalation, but in comparison to oral intake, all other routes are negligible [28]. According to toxicological effects, the health risks of exposed pollutants include carcinogenic and non-carcinogenic risks. The current general health risk assessment system was developed by the US EPA, and the formula for the relevant parameters is as follows:

$$
C D I_{\text {ing }}=\frac{C W \times I R \times E F}{B W \times A T}
$$

...where $C D I_{\text {ing }}$ represents the chronic daily intake via ingestion (oral exposure) $(\mathrm{mg} /(\mathrm{kg} \cdot \mathrm{d})), \mathrm{Cw}$ represents the concentration of heavy metals $\left(\mathrm{mg} \cdot \mathrm{L}^{-1}\right)$, IR represents the drinking water ingestion rate $\left(2 \mathrm{~L} \cdot\right.$ day $\left.^{-1}\right)$, EF represents the exposure frequency (365 day/year), ED represents the exposure duration (70 year), BW is the body weight $(70 \mathrm{~kg}$ ) and AT is the average time (365 day/year $\times 70$ year $=25,550$ days) $[29]$.

$$
H Q_{i n g}=\frac{C D I_{\text {ing }}}{R f D}
$$

$H Q_{\text {ing }}$ (the hazard quotient index) represents the non-carcinogenic risk $(\mathrm{mg} /(\mathrm{kg} \cdot \mathrm{d}))$, and $\mathrm{RfD}$ represents the reference dose of the heavy metal $(\mathrm{mg} /(\mathrm{kg} \cdot \mathrm{d})$ ); the oral toxicity reference dose $(\mathrm{RfD})$ values are 0.3 $(\mathrm{Zn}), 0.037(\mathrm{Cu}), 0.036(\mathrm{~Pb}), 0.02(\mathrm{Ni})$, and $0.14(\mathrm{Mn})$ $\mathrm{mg} /(\mathrm{kg} \cdot \mathrm{d})[30]$.

$$
\mathrm{CR}=C D I_{\text {ing }} \times S F
$$

The carcinogenic risk (CR) from the ingestion of heavy metals in drinking water is typically predicted by the above equation; SF is the coefficient of the carcinogenic dose of the chemical pollutant $(\mathrm{mg} /(\mathrm{kg} \cdot \mathrm{d}))$. The International Association for Research on Cancer (IARC) and the World Health Organization (WHO) conducted a comprehensive assessment of the carcinogenicity of chemical pollutants and developed a corresponding classification system; in this study, only $\mathrm{Cd}$ belongs to the carcinogenic chronic chemical pollutants, and the reference dose value of $\mathrm{Cd}$ is $6.1 \mathrm{mg} / \mathrm{kg} \cdot \mathrm{d}$ [31]. In most regulatory programmes, a $\mathrm{CR}$ value of more than $1.00 \mathrm{E}-05$ indicates a potential carcinogenic risk [32].

\section{Results and Discussion}

\section{Distribution Characteristics of Heavy Metals in Surface Water from the Syr Darya River}

The results of the metal analysis for the 42 samples are provided in Table 1 . The presence of $\mathrm{Zn}, \mathrm{Cu}, \mathrm{Pb}, \mathrm{Cd}$, $\mathrm{Ni}, \mathrm{Co}, \mathrm{Mn}$, and $\mathrm{Fe}$ was observed with concentrations within the ranges of $0.027-0.169,0.002-0.034$, $0.000-0.023,0.015-0.085,0.008-0.105,0.014-0.691$ and $0.125-8.180 \mathrm{mg} \cdot \mathrm{L}^{-1}$, respectively. The mean value of heavy metals in the surface water were in the order of $\mathrm{Fe}>\mathrm{Mn}>\mathrm{Zn}>\mathrm{Ni}>\mathrm{Co}>\mathrm{Cu}>\mathrm{Cd}>\mathrm{Pb}$. The coefficient of variation (CV) is the percentage of the standard deviation relative to the average value of each element, which reflects the degree of dispersion of the elements among the samples. The smaller the CV, the lower the degree of dispersion; the greater the $\mathrm{CV}$, the higher the degree of dispersion. Generally, the degree of variation of a sample can be divided into three levels: $\mathrm{CV}<10 \%$ is a weak variation, $10 \% \leq \mathrm{CV} \leq 100 \%$ is a moderate variation, and $\mathrm{CV}>100 \%$ is a strong variation [33]. The results showed that $\mathrm{Zn}, \mathrm{Cu}, \mathrm{Pb}, \mathrm{Cd}, \mathrm{Ni}, \mathrm{Co}$, $\mathrm{Mn}$, and $\mathrm{Fe}$ have coefficients of variation higher than $30 \%$; in particular, the coefficients of variation of $\mathrm{Mn}$ and $\mathrm{Pb}$ are over $100 \%$, which indicate strong variability. These results indicate that there are obvious regional differences in the contents of these elements.

The results of the spatial distribution analysis of metals are provided in Fig. 2. Overall, the concentrations of $\mathrm{Zn}, \mathrm{Pb}$ and $\mathrm{Mn}$ in the water samples showed a clear decreasing trend along the river, and there were 15 water samples in which no $\mathrm{Pb}$ was detected. The high concentrations of the heavy metals $\mathrm{Zn}, \mathrm{Pb}$

Table 1. Dissolved metals in the Syr Darya River, Kazakhstan (unit: $\mathrm{mg} \cdot \mathrm{L}^{-1}$ )

\begin{tabular}{|c|c|c|c|c|c|c|}
\hline Heavy metal & Mean & Standard deviation & Range & Minimum & Maximum & CV (\%) \\
\hline $\mathrm{Zn}$ & 0.078 & 0.025 & 0.142 & 0.027 & 0.169 & 31.520 \\
\hline $\mathrm{Cu}$ & 0.016 & 0.008 & 0.032 & 0.002 & 0.034 & 48.470 \\
\hline $\mathrm{Pb}$ & 0.003 & 0.005 & 0.023 & 0.000 & 0.023 & 171.770 \\
\hline $\mathrm{Cd}$ & 0.008 & 0.005 & 0.021 & 0.002 & 0.023 & 63.100 \\
\hline $\mathrm{Ni}$ & 0.051 & 0.017 & 0.070 & 0.015 & 0.085 & 32.750 \\
\hline $\mathrm{Co}$ & 0.048 & 0.020 & 0.097 & 0.008 & 0.105 & 41.570 \\
\hline $\mathrm{Mn}$ & 0.144 & 0.172 & 0.677 & 0.014 & 0.691 & 119.970 \\
\hline $\mathrm{Fe}$ & 2.303 & 2.180 & 8.055 & 0.125 & 8.180 & 94.660 \\
\hline
\end{tabular}


and $\mathrm{Mn}$ concentrated near the Arys River tributary of the Syr Darya River may be related to the Arys River itself, which receives sewage water from industrial activities in the town of Shymkent and other residential areas upstream [16], and may also receive pollutants from the mining, metallurgy and chemical industries in upstream countries [18]. Some high concentrations of $\mathrm{Cu}$ were observed in water samples near the Arys River, which could be due to the accumulation of sewage water from industrial activities in the town of Shymkent and the mineral deposits surrounding the Arys River, and another high concentration of $\mathrm{Cu}$ near
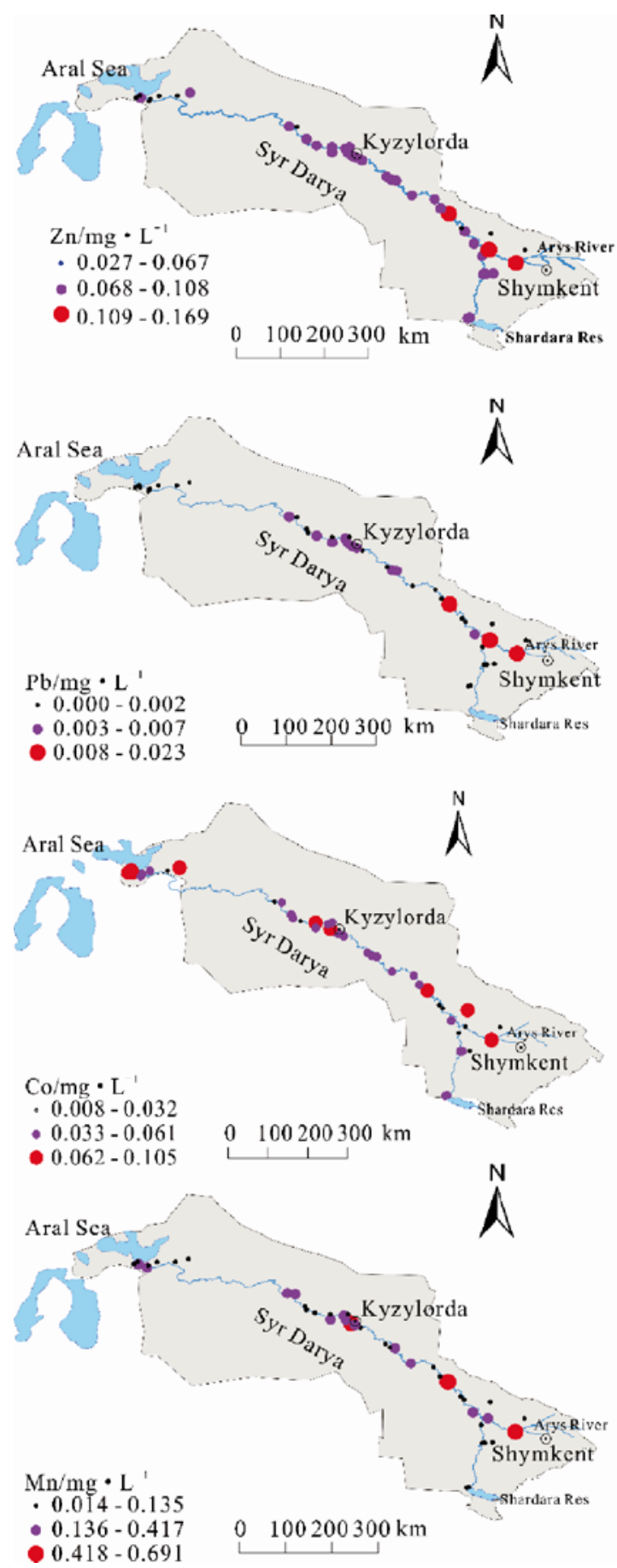

the Aral Sea may be due to the gradual accumulation of upstream pollution. The high concentrations of $\mathrm{Cd}$ concentrated in the Kyzylorda and the Aral Sea and may be due to industrial and agricultural pollution nearby, and gradual accumulation of upstream pollution, the high point near the Arys River due to the sampling points are located in a small reservoir. The high concentrations of $\mathrm{Co}$ and $\mathrm{Fe}$ concentrated near Kyzylorda may be due to pollution from the mineral field near the town of Shield, and the concentrations in the Aral Sea may be due to the gradual accumulation of upstream pollution [16].
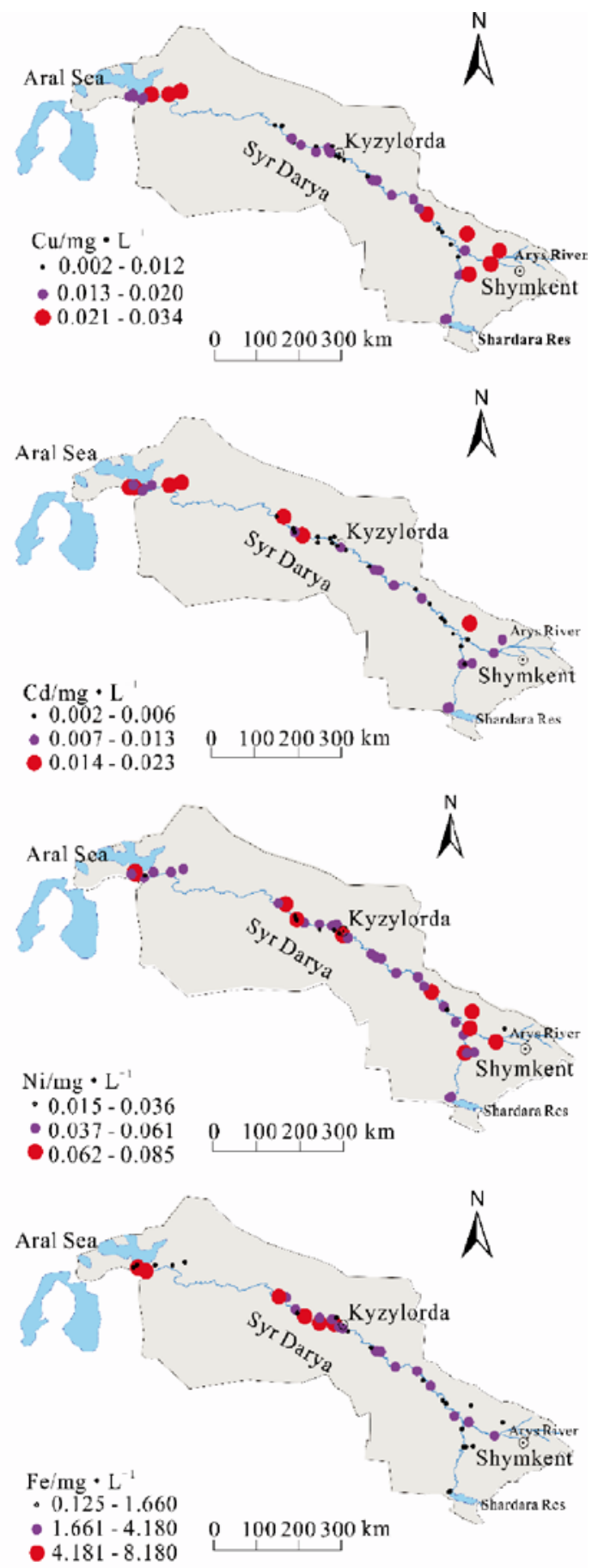

Fig. 2. Spatial distribution characteristics of heavy metals. 
The changing trend of $\mathrm{Ni}$ is relatively stable, indicating that there are many Ni sources along the river. The spatial distribution map further proved the obvious regional differences in the contents of these heavy metals, and further statistical analysis will indicate how harmful these heavy metals are.

\section{Comparison with the Strict Fishery Standards of MPC}

Kazakhstan's fisheries have great potential for economic development and environmental sustainability, but the environmental problems caused by human activities pose a great threat to this industry [34]. In the countries of Central Asia, the strictestmaximum-permissible-concentrations standards for fishery pools are generally used for assessing surface water quality [35]. In comparison with the MPCs of $\mathrm{Zn}$ $\left(0.01 \mathrm{mg} \cdot \mathrm{L}^{-1}\right), \mathrm{Cu}\left(0.001 \mathrm{mg} \cdot \mathrm{L}^{-1}\right), \mathrm{Pb}\left(0.006 \mathrm{mg} \cdot \mathrm{L}^{-1}\right), \mathrm{Cd}$ $\left(0.005 \mathrm{mg} \cdot \mathrm{L}^{-1}\right)$, Ni $\left(0.01 \mathrm{mg} \cdot \mathrm{L}^{-1}\right)$, Co $\left(0.01 \mathrm{mg} \cdot \mathrm{L}^{-1}\right), \mathrm{Mn}$ $\left(0.01 \mathrm{mg} \cdot \mathrm{L}^{-1}\right)$ and $\mathrm{Fe}\left(0.1 \mathrm{mg} \cdot \mathrm{L}^{-1}\right)$ for fisheries [36], the average concentrations of the above heavy metals, except $\mathrm{Pb}$, all exceed their respective MPCs, the concentrations of $\mathrm{Cu}, \mathrm{Mn}$ and $\mathrm{Fe}$ have high relative values of 16.00 MPC, 14.40 MPC and 23.03 MPC, and Zn, Cd, Ni, Co with relative values of $7.80 \mathrm{MPC}, 1.60 \mathrm{MPC}, 5.10 \mathrm{MPC}$ and 4.80 MPC. The concentrations of $\mathrm{Zn}, \mathrm{Cu}, \mathrm{Ni}, \mathrm{Mn}$ and $\mathrm{Fe}$ in all water samples exceeded their MPC, and $\mathrm{Cd}$ and Co showed higher concentrations than their MPCs in $64.29 \%$ and $97.62 \%$ of water samples, respectively. Although the overall mean value of $\mathrm{Pb}$ did not exceed its MPC, 9.52\% of the water samples still exceeded permissible limits. The pollution severity is ranked as $\mathrm{Fe}>\mathrm{Cu}>\mathrm{Mn}>\mathrm{Zn}>\mathrm{Ni}>\mathrm{Co}>\mathrm{Cd}$.

The results of the above data indicate that the heavy metal pollution situation in the study area should be widely concerned. The Aral-Syr Darya is one of the major fishery waters in Kazakhstan, so its water environment safety has a direct impact on the fishery. The state of heavy metal pollution in river waters from abroad and within the country has been severe for a long time, and with the fishery being one of the pillars of economic development in the research region, fishery water environment quality has a potential impact on regional economic development. The results of the detection of heavy metal content in surface water of this study are higher than those of previous research results [16, 17, 37-41], which indicate that the heavy metal pollution of surface water in the region is developing in a more severe direction (Table 2). From a biological perspective, the presence of heavy metals may pose a threat to fish and other aquatic organisms that inhabit the Syr Darya River, and furthermore it can also threaten human health through bio-enrichment, so it is necessary to focus on strengthening the supervision and treatment of regional heavy metal pollution.

\section{Heavy Metal Pollution Index}

In order to understand the impact of heavy metals on overall water quality, we calculated the heavy metal pollution index, and the spatial distribution results are shown in Fig. 3. The average HPI value for the surface waters examined in this study is 72.221 , which was calculated using the average concentration of all the samples. This value is less than the critical value of 100 as proposed by Prasad and Bose [24]. However, considering the classes proposed by Edet and Offiong [27], the overall pollution index of the water considering heavy metals is classified as high (HPI $>30)$. The HPI results calculated for each sample point were quite different, and the values ranged from 21.504 to 193.079. The lowest value of the HPI appeared at the mouth of a small tributary branching from the mainstream, and the highest value of the HPI occurred in the Arys River, which is the largest tributary in the study area and a site of accumulation for pollution from industrial and agricultural activities, mining and other sources [16]. Considering the classes of HPI, the HPI values of all sample points were higher than 15 , with $7.14 \%$ of

Table 2. Heavy metal concentrations in the surface water of the Syr Darya River, Kazakhstan.

\begin{tabular}{|c|c|c|c|c|c|c|c|c|c|}
\hline \multirow{2}{*}{ Year } & \multicolumn{8}{|c|}{ Heavy metal concentrations, mg/L } & \multirow{2}{*}{ Ref } \\
\hline & $\mathrm{Zn}$ & $\mathrm{Cu}$ & $\mathrm{Pb}$ & $\mathrm{Cd}$ & $\mathrm{Ni}$ & Co & Mn & $\mathrm{Fe}$ & \\
\hline 1985 & 0.002 & 0.001 & - & - & - & - & - & - & [38] \\
\hline 1990 & 0.002 & 0.003 & - & - & - & - & - & - & \\
\hline 2000 & 0.006 & 0.004 & - & - & - & - & - & - & \\
\hline 2005 & 0.005 & 0.003 & - & - & - & - & - & - & \\
\hline 2010 & 0.007 & 0.004 & - & - & - & - & - & - & \\
\hline 2011 & 0.006 & 0.003 & - & - & - & - & - & 0.118 & [39] \\
\hline December 2000 & 0.028 & 0.002 & - & - & $<0.030$ & 0.003 & 0.013 & 0.368 & [40] \\
\hline June 2001 & 0.014 & - & - & - & $<0.030$ & 0.0004 & 0.035 & 0.176 & \\
\hline May 2013 & 0.021 & - & $<0.006$ & $<0.005$ & $<0.01$ & $<0.01$ & $<0.01$ & - & [16] \\
\hline
\end{tabular}




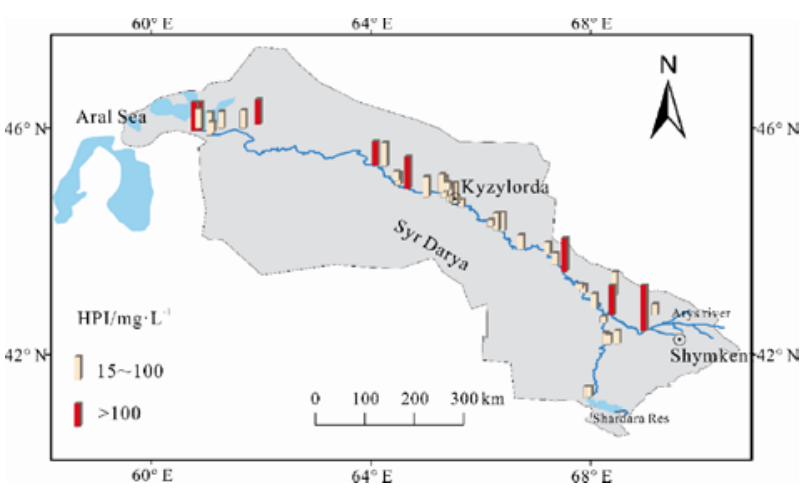

Fig. 3. HPI values of the surface water of the Aral-Syr Darya River at different locations.

the sample points at a medium level $(15<\mathrm{HPI}<30)$ and $92.86 \%$ of the sample points at a high level (HPI $>30)$. A total of $19.05 \%$ of the locations had HPI values above 100. Therefore, it can be inferred that the effect of these metals on the overall quality of water is poor because of mining, mineralization and industrial activities near some locations.

In addition, Pearson correlation analysis is used to understand the contribution of each metal on the impact of HPI values. The results (Table 3) showed that all the metals were significantly correlated with HPI, which indicates that these metals all could pose a strong influence on the HPI values.

\section{Human Health Risk Assessment}

Heavy metals may also pose a potential threat to human health, they may cause serious biological effects including carcinogenesis, DNA damage and cell death $[42,43]$. We used the human health risk assessment method as recommended by the U.S. EPA as a reference to assess the risk of heavy metals to human health in the water body of the study area. The results of the human health risk assessment are provided in Table 4. This study mainly discussed the index of chronic daily intake via ingestion (CDI), the hazard quotient (HQ) index of the non-carcinogenic risk of heavy metals and the index of the carcinogenic risk (CR). In the description of risk, the average and maximum values are used as highend estimates. In general, the exposed population is assumed to be safe when $\mathrm{HQ}<1$; otherwise, there might be potential adverse health effects, and further research might be needed. In this study, the results showed that the CDI values were less than 6.71E-05, 1.35E-05, 9.13E-06, 9.13E-06, 3.37E-05, 4.17E-05, 2.74E-04, and $3.25 \mathrm{E}-03 \mathrm{mg} /(\mathrm{kg} \cdot \mathrm{d})$ for $\mathrm{Zn}, \mathrm{Cu}, \mathrm{Pb}, \mathrm{Cd}, \mathrm{Ni}, \mathrm{Co}, \mathrm{Mn}$ and $\mathrm{Fe}$, respectively, and the mean $\mathrm{CDI}$ values followed the order of $\mathrm{Fe}>\mathrm{Mn}>\mathrm{Zn}>\mathrm{Ni}>\mathrm{Co}>\mathrm{Cu}>\mathrm{Cd}>\mathrm{Pb}$. The HQ values were less than 2.24E-04, 3.65E-04, 2.54E-04, 1.69E-03, and $1.96 \mathrm{E}-03 \mathrm{mg} /(\mathrm{kg} \cdot \mathrm{d})$ for $\mathrm{Zn}, \mathrm{Cu}$, $\mathrm{Pb}, \mathrm{Ni}$ and $\mathrm{Mn}$, respectively, and the mean HQ values followed the order of $\mathrm{Ni}>\mathrm{Mn}>\mathrm{Cu}>\mathrm{Zn}>\mathrm{Pb}$. In addition, none of the HQ values exceeded one, which means that the exposed population is assumed to be safe.

According to the classification system for chemicalpollution carcinogens developed by the International Association for Research on Cancer (IARC) and the World Health Organization (WHO), only Cd in this study was carcinogenic. The average and maximum CR values of $\mathrm{Cd}$ were $2.05 \mathrm{E}-05$ and $5.57 \mathrm{E}-05$, both of which are above $1.00 \mathrm{E}-05$, and approximately $76.19 \%$ of water samples exceeded the acceptable concentrations. It is known that the long-term absorption of cadmium can cause bone, lung and renal disease, and it has been documented that the kidney is the main organ affected by chronic $\mathrm{Cd}$ exposure and toxicity $[44,45]$. According to the calculated results, the oral ingestion of $\mathrm{Cd}$ can cause a significant carcinogenic risk to human health. Therefore, cadmium shall be used as a priority target of heavy-metal-pollutant control in the region to ensure the sustainable health of the aquatic ecosystem, and corresponding measures should be taken.

Table 3. Pearson correlation matrix between different metals in the surface water of the Syr Darya River in Kazakhstan $(\mathrm{n}=42)$.

\begin{tabular}{|c|c|c|c|c|c|c|c|c|c|}
\hline & $\mathrm{Zn}$ & $\mathrm{Cu}$ & $\mathrm{Pb}$ & $\mathrm{Cd}$ & $\mathrm{Ni}$ & $\mathrm{Co}$ & $\mathrm{Mn}$ & $\mathrm{Fe}$ & $\mathrm{HPI}$ \\
\hline $\mathrm{Zn}$ & 1.00 & 0.197 & $0.864 * *$ & -0.225 & 0.250 & 0.056 & $0.641^{* *}$ & $0.304^{*}$ & $0.532^{* *}$ \\
\hline $\mathrm{Cu}$ & & 1.000 & 0.218 & $0.519^{* *}$ & 0.209 & 0.203 & 0.063 & -0.156 & $0.416^{* *}$ \\
\hline $\mathrm{Pb}$ & & & 1.000 & -0.125 & $0.344^{*}$ & 0.090 & $0.806^{* *}$ & $0.407^{* *}$ & $0.727^{* *}$ \\
\hline $\mathrm{Cd}$ & & & & 1.000 & $0.403^{* *}$ & 0.272 & -0.152 & -0.084 & $0.513^{* *}$ \\
\hline $\mathrm{Ni}$ & & & & & 1.000 & 0.185 & 0.286 & -0.066 & $0.493^{* *}$ \\
\hline $\mathrm{Co}$ & & & & & & 1.000 & 0.129 & 0.100 & $0.355^{*}$ \\
\hline $\mathrm{Mn}$ & & & & & & & 1.000 & $0.485^{* *}$ & $0.670^{* *}$ \\
\hline $\mathrm{Fe}$ & & & & & & & & 1.000 & $0.533^{* *}$ \\
\hline $\mathrm{HPI}$ & & & & & & & & & 1.000 \\
\hline
\end{tabular}

*Correlation is significant at the 0.05 level (2-tailed)

**Correlation is significant at the 0.01 level (2-tailed) 
Table 4. Analysis of the effects of heavy metals on human health.

\begin{tabular}{|c|c|c|c|c|c|c|}
\hline \multirow{2}{*}{ Heavy metal } & \multicolumn{2}{|c|}{$\mathrm{CDI}(\mathrm{mg} /(\mathrm{kg} \cdot \mathrm{d}))$} & \multicolumn{2}{|c|}{ HQ } & \multicolumn{2}{|c|}{$\operatorname{CR}\left(\mathrm{a}^{-1}\right)$} \\
\hline & Mean & Max & Mean & Max & Mean & Max \\
\hline $\mathrm{Zn}$ & $3.10 \mathrm{E}-05$ & $6.71 \mathrm{E}-05$ & $1.03 \mathrm{E}-04$ & $2.24 \mathrm{E}-04$ & - & - \\
\hline $\mathrm{Cu}$ & $6.36 \mathrm{E}-06$ & $1.35 \mathrm{E}-05$ & $1.72 \mathrm{E}-04$ & $3.65 \mathrm{E}-04$ & - & - \\
\hline $\mathrm{Pb}$ & $1.08 \mathrm{E}-06$ & 9.13E-06 & $3.01 \mathrm{E}-05$ & $2.54 \mathrm{E}-04$ & - & - \\
\hline $\mathrm{Cd}$ & 3.37E-06 & $9.13 \mathrm{E}-06$ & - & - & $2.05 \mathrm{E}-05$ & 5.57E-05 \\
\hline $\mathrm{Ni}$ & 2.03E-05 & $3.37 \mathrm{E}-05$ & $1.01 \mathrm{E}-03$ & $1.69 \mathrm{E}-03$ & - & - \\
\hline $\mathrm{Co}$ & $1.92 \mathrm{E}-05$ & 4.17E-05 & - & - & - & - \\
\hline $\mathrm{Mn}$ & $5.70 \mathrm{E}-05$ & 2.74E-04 & 4.07E-04 & $1.96 \mathrm{E}-03$ & - & - \\
\hline $\mathrm{Fe}$ & $9.14 \mathrm{E}-04$ & $3.25 \mathrm{E}-03$ & - & - & - & - \\
\hline
\end{tabular}

\section{Conclusions}

The distribution characteristics and assessment of heavy metals ( $\mathrm{Zn}, \mathrm{Cu}, \mathrm{Pb}, \mathrm{Cd}, \mathrm{Ni}, \mathrm{Co}, \mathrm{Mn}, \mathrm{Fe})$ in the surface water of the Syr Darya river in Kazakhstan were investigated and analyzed.

The characterization and spatial distribution of the general heavy metal pollution in this region showed that there are obvious regional differences in the contents of $\mathrm{Zn}, \mathrm{Cu}, \mathrm{Pb}, \mathrm{Cd}, \mathrm{Ni}, \mathrm{Co}, \mathrm{Mn}, \mathrm{Fe}$, the high concentrations of these heavy metals is mainly concentrated near the Arys River tributary, Kyzylorda or the Aral Sea, and it may be due to the influence of human activities.

The mean values of all heavy metals exceeded the strict fishery standards of MPCs, except for $\mathrm{Pb}$, for which the concentrations of four water samples $(9.52 \%)$ still exceeded the MPC value. In addition, pollution severity was ranked as $\mathrm{Fe}>\mathrm{Cu}>\mathrm{Mn}>\mathrm{Zn}>\mathrm{Ni}>\mathrm{Co}$ $>\mathrm{Cd}$. These results indicate that the impact of current heavy metal concentrations on fisheries is worrying.

The HPI ranged from 21.504 to 193.079 with an average of 72.221 , and the HPI values of all samples were higher than 15 , with $7.14 \%$ of samples at a medium level $(15<\mathrm{HPI}<30), 92.86 \%$ of samples at a high level (HPI $>30$ ), and $19.05 \%$ of samples with HPI values above 100 ; these values mean that the heavy metal pollution in the study area is high.

The health risk assessment of heavy metal concentrations in surface water in the study area indicated that the non-carcinogenic risks (HQs) of heavy metals were all below one, which means that the exposed population is assumed to be safe, and the carcinogenic risk (CR) showed that the oral ingestion of $\mathrm{Cd}$ can cause a significant carcinogenic risk to human health and that this element should be used as a priority target of heavy-metal-pollutant control in the region.

Therefore, in order to control the impact of heavy metals on the aquatic environment and human health, adequate strategies and management plans should be formulated and implemented as soon as possible.

\section{Acknowledgements}

This research was funded and supported by the National Natural Science Foundation of China (U1603242), the Science and Technology Service Network Initiative (KFJ-STS-QZYD-071), the Foundation of State Key Laboratory of Desert and Oasis Ecology, Xinjiang Institute of Ecology and Geography Chinese Academy of Sciences, the CAS "Light of West China" Program (2017-XBQNXZ-B-012) and the Training Program for Youth Innovative Talents in Science and Technology in Xinjiang (QN2016BS0052).

\section{Conflict of Interest}

The authors declare no conflict of interest.

\section{References}

1. WONGSASULUK P., CHOTPANTARAT S., SIRIWONG W., ROBSON M. Heavy metal contamination and human health risk assessment in drinking water from shallow groundwater wells in an agricultural area in UbonRatchathani province, Thailand. Environmental Geochemistry \& Health, 36 (1), 169, 2014.

2. ISMAIL A., TORIMAN M.E., JUAHIR H., ZAIN S.M., HABIR N.L.A., RETNAM A., KAMARUDDIN M.K.A., UMAR R., AZID A. Spatial assessment and source identification of heavy metals pollution in surface water using several chemometric techniques. Marine Pollution Bulletin, 106 (1-2), 292, 2016.

3. ARMITAGE P.D., BOWES M.J., VINCENT H.M. Long-term changes in macroinvertebrate communities of a heavy metal polluted stream, the river Nent (Cumbria, UK) after 28 years. River Research \& Applications, 23 (9), 997, 2010.

4. YUAN G.L., LIU, C., CHEN L., YANG Z. Inputting history of heavy metals into the inland lake recorded in sediment profiles, Poyang Lake inChina. Journal of Hazardous Materials, 185 (1), 336, 2011.

5. SU S., XIAO R., MI X., XU X., ZHANG Z., WU J. Spatial determinants of hazardous chemicals in surface water of 
QiantangRiver,China. Ecological Indicators, 24 (24), 375, 2013.

6. ISLAM M.S., HAN S., AHMED M.K., MASUNAGA S. Assessment of trace metal contamination in water and sediment of some rivers in Bangladesh. Journal of Water and Environment Technology, 12 (2), 109, 2014.

7. ALLOWAY B.J., AYRES D. Chemical principles of environmental pollution. Water Air \& Soil Pollution, 102 (1-2), 216, 1998.

8. SHAH M.T., ARA J., MUHAMMAD S., KHAN S., TARIQ S. Health risk assessment via surface water and sub-surface water consumption in the mafic and ultramafic terrain, Mohmand agency, northern $\mathrm{P}$ akistan. Journal of Geochemical Exploration, 118, 60, 2012.

9. WASEEM A., ARSHAD J., IQBAL F., SAJJAD A., MEHMOOD Z., MURTAZA G. Pollution status of Pakistan: a retrospective review on heavy metal contamination of water, soil, and vegetables. Biomed Res Int, 813206, 2014.

10. RAZAK N.H.A., PRAVEENA S.M., ARIS A.Z., HASHIM Z. Drinking water studies: a review on heavy metal, application of biomarker and health risk assessment (a special focus in Malaysia). J Epidemiol Glob Health, $\mathbf{5}$ (4), 297, 2015.

11. COEURDASSIER M., SCHEIFLER R., MENCH M., CRINI N., VANGRONSVELD J., VAUFLEURY A. Arsenic transfer and impacts on snails exposed to stabilized and untreated As-contaminated soils. Environmental pollution, 158 (6), 2078, 2010.

12. MAHMUDOV I.E., MURADOV N., BEKMAMADOVA G. Evaluation of the Management and Use of Water Resources in the Middle Reaches of the Syr Darya Basin (Chirchik-Akhangaran-Keles Irrigation District). Advanced Engineering Forum, 18, 75, 2016.

13. LIPPONEN A. Challenges and Opportunities for Transboundary Water Cooperation in Central Asia: Findings from UNECE's Regional Assessment and Project Work[J]. International Journal of Water Resources Development, 28 (3), 565, 2012.

14. KULMATOV R, HOJAMBERDIEV M. Distribution of heavy metals in atmospheric air of the arid zones in Central Asia. Air Quality Atmosphere \& Health, 3 (4), 183, 2010.

15. KADYRZHANOV K.K., BARBER D.S., SOLODUKHIN V.P., POZNYAK V.L., KAZACHEVSKIY I.V., KNYAZEV B.B., LUKASHENKO S.N., KHAZHEKBER S., BETSILL J.D., PASSELL H.D. Radionuclide contamination in the Syrdarya river basin of Kazakhstan, Results of the Navruz Project. Journal of Radioanalytical \& Nuclear Chemistry, 263 (1), 197, 2005.

16. SOLODUKHIN V.P., POZNYAK V.L., KAZACHEVSKIY I.V., KNYAZEV B.B., LUKASHENKO S.N., KHAZHEKBER S. Some peculiarities of the contamination with radionuclides and toxic elements of the Syrdarya river basin, Kazakhstan. Journal of Radioanalytical \& Nuclear Chemistry, 259 (2), 245-, 2004.

17. SATYBALDIYEVB., TUOVINEN H., URALBEKOV B., LEHTO J., BURKITBAYEV M. Heavy metals and natural radionuclides in the water of Syr Darya River, Kazakhstan. Uranium - Past and Future Challenges, 34 (8), 155, 2015.

18. KADYRZHANOV K.K., PASSELL H.D., SOLODUKHIN V.P., KHAZHEKBER S., POZNYAK V.L., CHERNYKH E.E. Radiation and Hydro-Chemical Investigation and
Monitoring of Transboundary Rivers of Kazakhstan. Springer Netherlands, 35, 2008.

19. URALBEKOV B., LEHTO J., TUOVINEN H., SATYBALDIYEV B., BURKITBAYEV M. Heavy metals and natural radionuclides in the water of Syr Darya River, Kazakhstan, proceedings of the International Conference on Uranium Mining and Hydrogeology, F, 2014.

20. DENG M.J. International cooperation problems on transboundary rivers in Kazakhstan. Arid Land Geography, 35, 365, 2012.

21. GIRI S., SINGH A. K. Assessment of Surface Water Quality Using Heavy Metal Pollution Index in Subarnarekha River, India. Water Quality Exposure \& Health, 5 (4), 173, 2014.

22. PRASAD B., KUMARI P., BANO S., KUMARI S. Ground water quality evaluation near mining area and development of heavy metal pollution index. Applied Water Science, 4 (1), 11, 2014.

23. TIWARI A.K., DE M.M., SINGH P.K., MAHATO M.K. Evaluation of Surface Water Quality by Using GIS and a Heavy Metal Pollution Index (HPI) Model in a Coal Mining Area, India. Bulletin of Environmental Contamination \& Toxicology, 95 (3), 304, 2015.

24. PRASAD B., BOSE J. Evaluation of the heavy metal pollution index for surface and spring water near a limestone mining area of the lower Himalayas. Environmental Geology, 41 (1-2), 183-, 2001.

25. SANITARY RULES. "Sanitary and epidemiological requirements for water sources, water intake points for domestic and drinking purposes, domestic and drinking water supply and places of cultural and household water use and safety of water bodies" No. 104 SanPiN dated January 18. 2012 [In Russian].

26. WHO. Guidelines for drinking-water quality, 4 edn. World Health Organization, Geneva. 2011.

27. EDET A.E., OFFIONG O.E. Evaluation of water quality pollution indices for heavy metal contamination monitoring. A study case from Akpabuyo-Odukpani area, Lower Cross River Basin (southeastern Nigeria). Geojournal, 57 (4), 295, 2002.

28. ATSDR Toxicological Profile for Arsenic, TP-92/02. Agency for Toxic Substance and Disease Registry, U.S. Department of Health and Human Services, Atlanta, GA. 1993.

29. US EPA. Exposure Factors Handbook. Washington DC, USA. 1997.

30. US EPA. Guidelines for Exposure Assessment, EPA/630/ P-03/001F, Risk Assessment Forum, Washington, DC. 2005.

31. GAO B., LI Q., HUANG Y. Application of ICP-MS in the Health Risk Assessment of Heavy Metals for Drinking Water Sources in Reservoirs. Spectroscopy \& Spectral Analysis, 34 (5), 1398, 2014.

32. CAYLAK E. Health risk assessment for trace metals, polycyclic aromatic hydrocarbons and trihalomethanes in drinking water of Cankiri, Turkey. Journal of Chemistry, 9 (4), 1976, 2012.

33. ZHOU J., FENG K., PEI Z., LU M. Pollution assessment and spatial variation of soil heavy metals in Lixia River Region of Eastern China. Journal of Soils \& Sediments, 16 (3), 748, 2016.

34. SUTTON W., DIFFREY S., PETR T. Innovations in fisheries management for Kazakhstan. 2005.

35. SICICWC, UNECEC. Water quality in the Amudarya and SyrdarryaRive Basin, 2011. 
36. The list of fishery standards. Maximum Permissible Concentrations (MPCs) and Approximately Safe Levels of Exposure (ASLE) for harmful substances for water of water bodies that are of fishery importance. -M.VNIRO Publishing House, 1999-304c. [In Russian].

37. ASHENOVICH A.S. Present Situation of Ecological Environment and Strategy of Sustainable Development in Major Fishery Water in Republic of Kazakhstan. Journal of Hydroecology, 6, 028,2011 [In Chinese].

38. KULMATOV R.A., HOJAMBERDIEV M. Heavy Metals Concentration and Speciation in Arid Zone Rivers (Amudarya and Syrdarya) of Central Asia. Journal of environmental Science and Engineering, 4 (8), 36, 2010.

39. MUSTAFAYEV J.S., KOZYKEEVA A.T., ABDULIYEVA K.S. Geoecological assessment of transformation of the concentration of polluting substances in the waters of the lows of the Syrdarya river. Hydrometeorology and Ecology, 1, 160, 2017 [In Russian].

40. BURLIBAEV M.ZH., AMIRGALIEV N.A., SCHOENBERGER I.V., PEREVALOV A.S., BURLIBAEVA D.M. Modern mode of hydrochemical and toxicological parameters of the cross-border flow of the Syrdarya river and character of their transformation in the limits of Kazakhstan. Hydrometeorology and Ecology, 3, 141, 2013 [In Russian].
41. PASSELL H.D., BARBER D.S., BETSILL J.D., LITTLEFIELD A.C., MOHAGHEGHI A.H., SHANKS S.T., YULDASHEV B., SAALIKHBAEV U., RADYUK R., DJURAEV A., DJURAEV A., VASILEV I., TOLONGUTOV B., VALENTINA A., SOLODUKHIN V., POZNIAK V. The Navruz Project: Transboundary Monitoring for Radionuclides and Metals in Central Asia Rivers. Data Report. Sandia National Labs., 133, 2003.

42. WANG Z., MEADOR J.P., LEUNG K.M. Metal toxicity to freshwater organisms as a function of $\mathrm{pH}$ : A metaanalysis. Chemosphere, 144, 1544, 2016.

43. TCHOUNWOU P.B., YEDJOU C.G., PATLOLLA A.K., SUTTON D.J. Heavy Metal Toxicity and the Environment. EXS, 101 (101), 133, 2012.

44. JOHRI N., JACQUILLET G., UNWIN R. Heavy metal poisoning, the effects of cadmium on the kidney. Biometals, 23 (5), 783, 2010.

45. UNISA S., JAGANNATH P., DHIR V., KHANDELWAL C., SARANGI L., ROY T.K. Population-based study to estimate prevalence and determine risk factors of gallbladder diseases in the rural Gangetic basin of North India. Hpb the Official Journal of the International Hepato Pancreato Biliary Association, 13 (2), 117, 2011. 